\title{
Internationalisation motives and the multinationality- performance relationship: The case of Polish firms
}

\author{
Krystian Barłożewski, Piotr Trąpczyński
}

\begin{tabular}{|c|c|}
\hline \multicolumn{2}{|r|}{ A B S T R A C T } \\
\hline \multicolumn{2}{|c|}{$\begin{array}{l}\text { Objective: The objective of the article is to investigate the moderating role of internationalisation motives on } \\
\text { the multinationality-performance relationship of Polish firms. }\end{array}$} \\
\hline \multicolumn{2}{|c|}{$\begin{array}{l}\text { Research Design \& Methods: Our article uses panel regression models on a dataset of } 97 \text { Polish listed "new" } \\
\text { MNEs with foreign activities established in the period of } 2006-2013 \text {, gathered in a primary study. }\end{array}$} \\
\hline \multicolumn{2}{|c|}{$\begin{array}{l}\text { Findings: We found that Polish firms show an inverted U-curve relationship between multinationality and per- } \\
\text { formance, which is contrary to the predictions resulting from the traditional S-curve analysis. Moreover, we } \\
\text { found that political-institutional motives positively moderate the multinationality-performance curve for sales } \\
\text { growth, while efficiency-seeking motives have a similar effect on return on assets and return on sales. Finally, } \\
\text { competitiveness-related motivations behind internationalisation moderate the inverted U-shaped curve for } \\
\text { return on equity, although they are different than expected. }\end{array}$} \\
\hline \multicolumn{2}{|c|}{$\begin{array}{l}\text { Implications \& Recommendations: The article addresses the gap of limited consideration for the stage of in- } \\
\text { ternationalisation of the firms under study by focusing on early-stage ("new") MNEs. Secondly, as one of the } \\
\text { very few studies, our work follows some recent calls to unbundle the substance of internationalisation by } \\
\text { considering the moderating role of internationalisation motives. }\end{array}$} \\
\hline \multicolumn{2}{|c|}{$\begin{array}{l}\text { Contribution \& Value Added: This study helps to advance international business literature by testing longitu- } \\
\text { dinally the MP relationship for Polish firms between } 2006 \text { and } 2013 \text {. }\end{array}$} \\
\hline Article type: & \\
\hline & \\
\hline JEL codes: & \\
\hline & Revised: 9 \\
\hline
\end{tabular}

\section{Suggested citation:}

Barłożewski, K., \& Trąpczyński, P. (2021). Internationalisation motives and the multinationality-performance relationship: The case of Polish firms. Entrepreneurial Business and Economics Review, 9(2), 85-104. https://doi.org/10.15678/EBER.2021.090206

\section{INTRODUCTION}

The link between multinationality and performance (MP) has been an intensively debated research question for a couple of decades (Bausch \& Krist, 2007; Glaum \& Oesterle, 2007; Matysiak \& Bausch, 2012; Nguyen, 2017; Gugler, 2019). The research question is examined through the lens of several academic disciplines, including international business, strategic management, entrepreneurship, finance, and marketing (Kirca, Roth, Hult, \& Cavusgil, 2012; Obłój 2019). Extant literature predominantly focuses on establishing whether a general relationship between multinationality and performance exists and, furthermore, whether an ideal degree of internationalisation can be established. Despite a growing body of empirical research, the findings on the MP linkage remain inconsistent (Verbeke, Li, \& Goerzen, 2009) and often described as contradictory or confusing (Nguyen \& Kim, 2020). Some scholars attribute this situation to methodological limitations of extant research and call for a more in-depth exploration of contextual variables (Purkayastha, Sharma, \& Karna, 2020; Tallman \& Pedersen, 2012). 
Thus, recent years have brought a growing recognition that the MP linkage is contextual by nature, i.e. its shape depends on a number of moderating variables (Bausch \& Krist, 2007; Kirca et al., 2012; Geleilate, Magnusson, Parente, \& Alvarado-Vargas, 2016; Shin, Mendoza, Hawkins, \& Choi, 2017). Indeed, a number of factors identified in earlier studies can moderate the MP relationship, including firm-specific advantages and country-specific factors, e.g. firm size, industry, firm age, experience gathered in foreign market, R\&D investments, and institutions in the country of origin.

Some argue that - among these contextual variables - the appropriate understanding of performance outcomes of internationalisation requires considering its underlying motives (Barłożewski \& Trąpczyński, 2021; Elango, 2012; Verbeke \& Brugman, 2009; Verbeke, Li, \& Goerzen, 2009; Singla \& George, 2013). In fact, firms expanding for different reasons will set their performance priorities in different areas, and hence the evaluation of internationalisation outcomes can be different for specific dimensions (Benito, 2015; Caputo, Pellegrini, Dabic, \& Dana, 2016). Thus, internationalisation motives might be a critical variable altering the M-P relationship (Contractor, 2012; Verbeke \& Forootan, 2012). However, we must highlight that extant literature offers no extensive study on the role of motives as a contextual variable (Li, 2007; Nguyen, 2011; Ruigrok \& Wagner, 2004; Verbeke \& Brugman, 2009; Verbeke \& Forootan, 2012). While a number of factors associated with the international organisational structure of firms is used as explanatory variables, an investigation of strategic moderating factors remains mostly absent (Purkayastha et al., 2020). Jain and Prakash (2016) find a negative moderation of the MP relationship for the predominance of labour-seeking motives as opposed to market-seeking motives among Indian software firms. However, in doing so, they do not account for different performance effects of distinct motives, thus obscuring the actual implications of different types of foreign expansion. In fact, as in the case of many MP studies, there remains a disconnection between theoretical arguments and affected performance measures (Richter, Schmidt, Ladwig, \& Wulhorst, 2017), particularly as the results can vary greatly among specific measures (Mullen \& O'Hagan Luff, 2018).

In light of the above, the objective of this study is to investigate the moderating role of internationalisation motives on the multinationality-performance relationship, explicitly taking into account the multidimensional character of performance. In order to do so, the article uses panel regression models on a dataset of 97 Polish listed companies with foreign activities in the period of 2006-2013, with a total of 682 observations. Our study was set in the context of a post-transition economy in line with earlier calls to contribute to MP research progress by focusing on less advanced economies (Lopez-Morales \& Gomes-Casas, 2014; Geleilate et al., 2016). The post-transition context can pose an interesting opportunity for enriching existing international business concepts (Bučiūnienè, 2018; Paliokaite, 2019). Firms that originate from such an institutional setting were either created in the 1990s or existed before but without a chance to engage in international entrepreneurship (Sedziniauskiene, Sekliuckiene, \& Zucchella, 2019). Either way, these firms are new to international business, hence they can be referred to as newly internationalised firms (Hoskisson, Wright, Filatotchev, \& Peng, 2013; Ramamurti, 2009). Their study can help to advance MP research by focusing on the challenges of the early stage of international activities (Doryń \& Stachera, 2008; Karasiewicz, 2013).

Our study contributes to existing research in several ways. Firstly, it follows recent calls to unbundle the substance of internationalisation by considering the moderating role of internationalisation motives (Verbeke \& Brugman, 2009; Verbeke, Li, \& Rugman, 2009; Li, 2007; Verbeke \& Forootan, 2012; Jain \& Prakash, 2016; Tohidi, Ghorbani, \& Karhasi, 2020). Thirdly, it dissects the effect of internationalisation on distinct performance dimensions, thus contributing to a more multidimensional understanding of this relationship. Moreover, by considering sales growth, we depart from the predominant focus on accounting measures in existing studies, which we believe increases the robustness of performed analyses (Li, 2007; Richter et al., 2017; Verbeke \& Forootan, 2012).

This article has the following structure. The literature section discusses the overall nature of the MP relationship in the light of earlier research. Subsequently, we consider the role of internationalisation motives in order to formulate research hypotheses. Further, the article details the research design. The following section focuses on regression results, and the article finishes with a number of suggestions for future research. 


\section{LITERATURE REVIEW}

\section{Conceptual overview}

The perspectives on the character of the MP relationship have evolved over years, only to end with no agreement among scholars (Matysiak \& Bausch, 2012; Verbeke \& Brugman, 2009; Verbeke \& Forootan, 2012; Berry \& Kaul, 2016). Firstly, researchers expected to detect a simple direct positive relationship between internationalisation and performance. Some argued that benefits of internationalisation would outweigh potential costs (Rugman \& Oh, 2011). In subsequent years, others questioned this view and tested negative linear MP linkage (Matysiak \& Bausch, 2012; Ruigrok \& Wagner, 2004). The proponents of simple direct relationship argued that foreign exchange costs and other would outweigh potential benefits derived from international expansion - after reaching some point costs arising from liability of newness, liability of foreignness, complexity of foreign operations, and costs of product adaptation to local demands (Li, 2007). However, there appeared a third option that showed no significant MP relationship (Sullivan, 1994).

Since the 1990s, the benefits and costs of foreign expansion are more closely verified, as scholars introduce new U-curve and inverted U-curve shapes (Matysiak \& Bausch, 2012; Annavarluja \& Beldona, 2000). The U-curve stresses the importance of learning in foreign markets, which may help to increase benefits and reduce costs that arise at the inception phase of internationalisation (Ruigrok \& Wagner, 2004; Rugman \& Oh, 2011). According to Contractor (2007), the U-curve shape is likely to occur in developing countries and young industries, in which only a small fraction of firms managed to achieve a high level of internationalisation. In turn, the inverted U-curve shape should accentuate the stage of over-internationalisation, in which the increased costs of expansion outweigh additional benefits. This might be explained by growing costs of coordinating foreign operations with increasing cultural, geographical, legal, and language differences (Contractor, 2007; Li, 2007; Glaum \& Oesterle, 2007; Gorynia et al., 2019). To reconcile the conflicting results, both curves were combined and a new, S-curve relationship with three stages was proposed (Contractor, Kundu, \& Hsu, 2003). The first stage of early internationalisation refers to the dominating liability of newness and foreignness over initial benefits from expanding abroad. The second stage reflects the effect of scale economies and learning after a certain point. The last stage exhibits costs that arise from over-internationalisation and decreasing benefits (Riahi-Belkaoui, 1998). More recently, an M-curve relationship was proposed to explain performance changes of INVs (International New Ventures), i.e. young companies that started internationalisation from their inception. The proposal extends the S-curve and assumes that there is one more initial stage at very low levels of multinationality, in which INVs achieve net performance gains thanks to entering foreign markets (Lee, 2010). The last proposition is an inverted M-curve, which can be observed for firms following product customisation strategies (Almodovar, 2012).

In the context of post-transition economies and based on some earlier evidence, we argue that the internationalisation degree generally leads to better results than focusing solely on the local market. Usually, this result is explained by a set of benefits that may be derived from expanding abroad, including firms' greater flexibility, risk diversification, enhanced image, acquired knowledge and skills, ownership, and economies of scale (Wach, 2017; Szałucka, 2013; Cieślik et al., 2019, Cieślik et al., 2018; Kosach, Duka, Starchenko, Myhaylovska, \& Zhavoronok, 2020). In general, firms should overcome costs of international expansion that may include e.g. costs of organisational change, coordination of entities and activities on foreign markets, monitoring of external providers, and institutional and cultural distance (Contractor, 2012).

Contrary to the opinion of some scholars on CEE firms' internationalisation, we suggest that due to a relatively low level of internationalisation - there is no necessity for these newly internationalised firms to invest extensive resources at the very first stage of foreign expansion. This is largely because at the beginning they may receive only occasional sales orders that do not require a particular customisation of products and value chains. This agrees with the argument about the 
predominance of market-seeking firms amongst firms from Central and Eastern Europe (Barłożewski, 2018; Gorynia, Nowak, Trąpczyński, \& Wolniak, 2016). Even though they start foreign operations at a larger scale, new MNEs frequently seek opportunities in markets with a similar demand structure to their own, in order to be able to quickly expand their sales (Ramamurti, 2009). Such an approach further reduces costs of adaption to a new business environment. Hence, despite the lack of necessary knowledge, the predominant focus on competing with low prices and not quality, and also even due to the highly intensive competition in European markets, we argue that the short initial stage of internationalisation of Polish firms is linked to increasing performance, which represents the effect of "global illusion" identified by Almodovar (2012). However, we agree that shortly after companies undertake internationalisation in a more systematic manner, the liabilities of foreignness and related costs will increase, thus leading to performance declines (Gu, Yang, \& Strange, 2018). Some global companies can suffer performance losses due to ineffective communication in this stage (Nwabueze, \& Mileski, 2018; Haller, 2020). With accumulated business experience, firms eventually achieve a point of inflection, at which benefits from internationalisation begin to dominate over potential costs.

Accordingly, as a baseline effect for further discussion, we argue that there is an inverted U-curve $M-P$ relationship in the case of Polish firms:

H1: There is an inverted U-shaped relationship between multinationality and performance for newly internationalised firms from post-transition economies.

\section{Moderation hypotheses development}

International expansion follows a number of motives (Verbeke \& Brugman, 2009; Li, 2007; Jain \& Prakash, 2016; Verbeke \& Forootan, 2012; Witkowski et al., 2017; Pokorna et al., 2019; Lee \& Fernando, 2020). Internationalisation motives determine location choices, ownership structure, choice of entry modes, and expected returns from expanding abroad, e.g. increase in net profits, risk reduction, increase in market share, access to diverse resources, and avoidance of hostile home-country conditions (Verbeke, Li, \& Goerzen, 2009; Benito, 2015; Miller, Lavie, \& Delios, 2016; Caputo et al., 2016). Moreover, let us underline that firms can be driven by a set of various internationalisation motives with similar significance, with distinct effects on firm performance in the long term.

There are a few studies devoted to the impact of international strategy and its motives on foreign market performance. They generally indicate a contingency between motivations for investment and their performance outcomes. In fact, internationalisation can fulfil a number of objectives from the headquarters' viewpoint (Demirbag, Tatoglu, \& Glaister, 2007). Thus, it is the very motives behind particular expansion decisions that drive performance in its specific dimensions (Verbeke \& Brugman, 2009; Verbeke, Li, \& Goerzen, 2009). While this claim might seem intuitive at first glance, business reality shows that pre-defined targets for foreign expansion are far from guaranteed, often resulting in strategy changes (Benito \& Welch, 1997). Thus, the verification of the relationship between motives and outcomes provides a direct indication as to the effectiveness of a firm's foreign expansion, particularly if we consider firms at early stages of internationalisation (Ramamurti, 2009).

Dunning (1988a; 1988b) argues that foreign expansion is undertaken to fulfil certain goals from the headquarters' perspective. These motives include strategic asset-, market-, and efficiency-seeking (Dunning, 1993). The first category of motives embraces firms that expand abroad in order to increase their international market share. Apart from market size and expected growth, such an expansion can be driven by the fact that a firm's key competitors, suppliers, or clients may establish themselves in a given market and incite the focal firm to follow them. Furthermore, the quest for additional sales in a foreign market may require a more substantial degree of adaptation to local market specificity. Moreover, not least important is the fact that costs of delivering products or services to a foreign market may make it economically more viable to serve it through a more direct presence.

In empirical research on the link between the internationalisation degree and its economic outcomes, some studies that examine the impact of the percentage of foreign revenues on firm performance find that it affects returns on sales, albeit in different ways. In fact, Quian (2002) finds a positive 
effect, Capar and Kotabe (2003) observe a U-curved relationship, Contractor et al. (2003) and Li (2005) note a horizontal S-shaped effect, while Li and Quian (2004) find an inverted U-curve. In accordance with the outgoing argumentation that the impact of internationalisation on performance is contextdependent, we argue that the market-seeking focus in foreign expansion does not express itself in the direct effect of foreign sales on internationalisation performance, but it is moderated by the extent to which this foreign expansion is driven by market-seeking motivations. In fact, firms with dominant market-seeking motive of internationalisation will be most likely focused on using their own brands and trademarks to increase sales by expanding into new markets, which should mostly manifest itself in the growth of sales, market share, and volume sold (Benito, 2015). Moreover, empirical research on foreign affiliate performance identifies market-related objectives to affect sales performance more than other motivations (Demirbag, Tatoglu, \& Glaister, 2007). Thus, in the context of newly internationalised firms from transition economies, we propose that:

H2: The effect in $\mathrm{H} 1$ is positively moderated by market-seeking motives so that this effect will be the strongest for sales growth.

However, internationalisation is not only driven by market-related motives. Firm expansion can also be driven by institutional factors. North $(2011$, p. 3) defines institutions as "the rules of the game in a society or, more formally, are the humanly devised constraints that shape human interaction" (North, 2011, p. 3). Previous research based on this theoretical perspective to examine e.g. choices of foreign location (e.g. Globerman \& Shapiro, 1999; Habib \& Zurawicki, 2002), market entry strategy (e.g. Estrin, Baghdasaryan, \& Meyer, 2009; Rodriguez, Uhlenbruck, \& Eden, 2005; Yiu \& Makino, 2002; Głodowska et al. 2019; Maciejewski \& Wach, 2019), and outcomes of aforementioned decisions (e.g., Brouthers, Brouthers, \& Werner, 2008). Based on the institutional view, these studies generally argue that the higher quality and stability of the institutional framework of a foreign market leads to higher levels of activity by foreign firms. By expanding to different institutional frameworks, firms can evade market imperfections in their own markets or leverage imperfections in the host countries (Kindleberger, 1969).

We argue that newly internationalised firms from transition economies - which perceive institutional pull factors in foreign markets as fiscal incentives or, conversely, push factors related to deficiencies in the home country environment - may be more inclined to leverage foreign markets potential and develop sales more easily thanks to the said easier environment for doing business. Obviously, institutional incentives can also be related to efficiency-driven investments abroad, but the aforementioned market-seeking focus of newly internationalised firms from transition economies shifts attention to sales-related effects. We argue that at initial stages of sales-driven internationalisation, the marginal benefits for companies are increasing. In the same vein, Geringer et al. (2000) find support for the fact that the ratio of sales by foreign subsidiaries - i.e. established in foreign institutional frameworks - positively affects sales growth. Conversely, from a certain threshold, the addition of further markets driven by institutional incentives can be questioned in light of the positive marginal effects on sales growth, as with the higher advancement of international operations the strategic needs of firms should be balanced across other motives. In this vein, we formalise this moderating effect as:

H3: The effect in $\mathrm{H} 1$ is positively moderated by home and host country institutional motives so that this effect will be the strongest for sales growth.

Another important motivation for international expansion pertains to the rationalisation of a firm's overall business operations by reaping cost benefits in such areas as manufacturing or sales by either concentrating activities in new locations with favourable cost levels or better exploiting existing capabilities (Dunning, 1993; Benito, 2015). Firms driven by the efficiency-seeking motive may be more oriented towards the long-term reduction of supply and production risks and costs (Li, 2007; Verbeke \& Brugman, 2009; Krajcirova, Vaňová, \& Munk, 2019).

In the context of post-transition economies, research evidences that lower labour costs of the foreign markets affect firm performance in foreign markets (Chan, Isobe, \& Makino, 2008; Li et al., 2011; 
Uhlenbruck, 1997; Jansto, Polakovič, Hennyeyová, \& Slováková, 2019). For domestic enterprises it becomes risk factor in recruitment (Bilan, Mishchuk, Roshchyk, \& Joshi, 2020), however, foreign firm performance increases due to efficient labour attracting strategies. Taking into account that this strategic focus in international expansion will predominantly affect the cost side of performance due to lower production costs or costs of serving clients, we can obviously expect a positive effect on return on sales (ROS). However, from a certain threshold of efficiency-driven expansion (e.g. construction of new units in low-cost host countries), we may question the ability to generate new high-margin sales, given the early stage of development of newly internationalised firms.

However, we simultaneously argue that since efficiency-driven expansion is frequently related to the possession of foreign manufacturing units, cost savings are related to substantial investment in foreign production, logistics, and advanced technological assets, hence further improving the ratio of the return on assets (ROA). Therefore, the positive effects of such investments will be observed at first. Subsequently, the costs of depreciation and amortisation, but also costs related to current maintenance and operation of new systems, facilities, and equipment, will outweigh potential benefits in the medium term, thus reinforcing performance declines in the conventional inverted U-shape. Accordingly, we formalise this posited moderating effect as:

H4: The effect in $\mathrm{H} 1$ is positively moderated by efficiency-seeking motives so that this effect will be the strongest for ROS and ROA.

Finally, an important category of foreign expansion motives is related to enhancing the overall competitiveness of firms involved in international business operations (Trąpczyński, 2016; Androniceanu, Kinnunen, Georgescu, \& Androniceanu, 2020). By managing cross-border operations located in different countries, firms can gain access to various tangible and intangible resources that can be shared across the organisation (Dunning \& Lundan, 2008). Studies on foreign affiliate performance consistently demonstrate that the possession of intangible resources by parent firm favours foreign affiliate performance (Brouthers, Brouthers, \& Werner, 2008; Fang et al., 2013; Xia, Qiu, \& Zafar, 2007).

However, if the parent firm is to benefit from foreign expansion it must possess sufficient managerial capabilities (Hennart, 2012). Foreign expansion may be introduced either by transferring marketing knowledge to the foreign venture so as to enhance the international market position or managing knowledge transfers to learn from foreign affiliates and make new knowledge available to sister affiliates. Particularly in the case of emerging country firms - whose capabilities and experience with managing a growing international scale of activities are often inferior to their Western counterparts the development or acquisition of more sophisticated capabilities can be a crucial source of competitive advantage. For instance, core role of the international orientation in SMEs competitive advantage is proved for Polish ventures (Sikora, \& Baranowska-Prokop, 2018).

Accordingly, the acquisition of new capabilities matters for performance as it allows firms to access inputs unavailable in domestic input markets (Verbeke \& Brugman, 2009). Thus, given these otherwise unavailable new capabilities, the firm can realise more profit potential, since the absorbed know-how can arguably enable the realisation of higher margins owing to marketing capabilities and product quality, which usually stem from strategic asset-seeking by post-transition economy firms, including those from Poland. Hence, the return on sales can be expected to be particularly accentuated thanks to this type of internationalisation. At the same time, such an expansion should also manifest itself visibly in the return on equity (ROE) due to the fact that for the same equity, the firms that increase their profits are those that become more competitive in terms of e.g. strong brands or distribution channels. Hence, we propose that:

H5: The effect in $\mathrm{H} 1$ is positively moderated by motives related to competitive pressures so that this effect will be the strongest for ROS and ROE.

Figure 1 below summarises the conceptual development in the form of our research framework. 


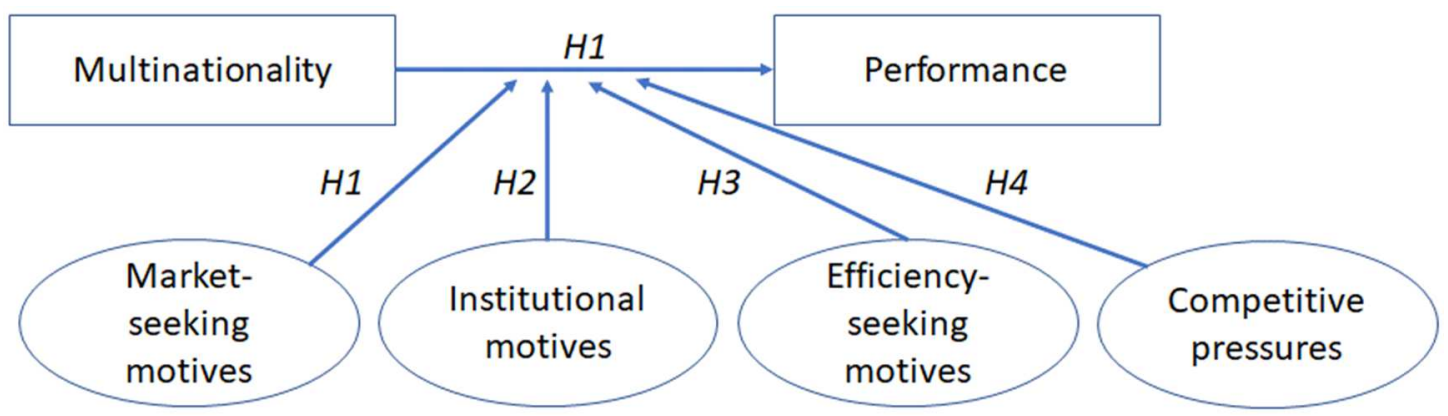

Figure 1. Analytical framework

Source: own elaboration.

\section{RESEARCH METHODOLOGY}

\section{Data collection}

Our analysis relied upon data obtained from 97 Polish listed newly internationalised firms with foreign activities established in the period of 2006-2013 (also see Barłożewski \& Trąpczyński, 2021). As data on foreign activities are not readily available, we needed to use a two-stages approach to building a proprietary database for further exploitation. Firstly, we obtained firm-level financial data from consolidated financial reports and further documentation issued by all Polish firms quoted on the Warsaw Exchange Stock for the period under scrutiny. The established database contained 335 companies. Among those companies, we compiled a sample of $143 \mathrm{firms}$ with $\mathrm{min} .5 \%$ of total sales revenues received in other countries for the last three years to be covered in the analysis.

In the second stage, primary survey data on 97 firms from the sample of 143 was collected using mix mode CATI+CAWI method (Computer Assisted Telephone Interviewing + Computer Assisted Web Interviews). The questionnaire consisted of questions relating to geo-graphical regions served, experience gained abroad, entry modes, and motives of internationalisation. The survey was conducted under the authors' supervision by Indicator, an external research agency. Data gathered at both stages was subsequently merged and as a result, we constructed a data set containing 97 firms and altogether 682 observations.

\section{Variable operationalisation}

\section{Dependent variable}

Performance as a dependent variable was measured using return on equity (ROE; net profits to equity), return on assets (ROA; net profits to total assets), return on sales (ROS; net profit to total revenue from sales), and sales growth (percentage change in annual total revenue from sales). All of these are accounting measures mostly used in the research of the MP relationship, mainly due to easy access to data (Glaum \& Oesterle, 2007) and because they are commonly used in extant research (Verbeke \& Brugman, 2009). The use of these distinct measures was important for us to indicate the differentiated effects of internationalisation led by different motives, as postulated in our research hypotheses.

\section{Explanatory variables}

The main explanatory variable was the internationalisation degree computed as foreign sales to total sales (FSTS). Other authors underline that this measure is very limited in scope, captures only one dimension of multinationality, and thus may present a distorted view of firms' advancement in foreign operations (Sullivan, 1994; Dörrenbächer, 2000). However, as FSTS is frequently used by scholars (Yang \& Driffield, 2012; Li, 2007; Bausch \& Krist, 2007), sometimes even recommended until a better measure is designed and developed (Rugman \& Oh, 2011), so we introduced the measure to the analysis due to very limited access to other data.

The moderating variables that make part of the research hypotheses were internationalisation motives. They were incorporated into the analysis using dummy variables representing market-seeking, 
efficiency-seeking, competitiveness-related, and political-institutional internationalisation motives. The market-seeking motives stood for firms' willingness to gain new markets for their products and services. Efficiency-seeking motives represented firms' goals to reduce costs and increase profitability. Motives related to competitiveness were linked to gaining competitive advantages by acquiring new resources like technology, knowledge, skills absent from the local market but available abroad. The last category of motives was understood as entering other countries because conditions for doing business in those markets improve or foreign investors receive additional benefits or new restricted laws and regulations are introduced in the home market. In order to define the dominant internationalisation motives for a given entity (market, efficiency, competitiveness, and politicalinstitutional), we formulated five detailed questions for each type. Answers were collected on a fivepoint Likert scale. The construction of questionnaire and rating values assigned to individual statements are described in Annex 1. For each of those motives, a firm-level compound index was designed and calculated (Cronbach's alpha coefficient greater than 0.5). The index represented the importance of a particular motive for a given company. Subsequently - regarding each motive - the sample was divided into two subsets with low and high value of the index, based on which adequate values for dummy variables were assigned.

\section{Control variables}

A series of control variables was added to the analysis so as to offset potential influences on performance known from extant literature.

Firm size (Bausch \& Krist, 2007; Ruigrok \& Wagner, 2004; Kirca et al., 2012) was measured as medium vs large company, which was defined based on criteria applied in the Polish law:

1. A large company employs more than 250 people, its annual sales revenue exceed PLN 200 mio. (ca. EUR 50 mio.) and total assets exceed PLN 172 mio. (ca. EUR 43 mio.).

2. A medium company has 50 to 249 employees, sales revenue and total assets exceed both PLN 40 mio. (ca. EUR 8 mio.).

Firm age was controlled for by dummy variables representing young firms (equal to or below 12 years of age) and old firms (above 12 years of age). Another variable was geographical diversification, which represented the number of regions (out of seven) in which a given company was present. A further control variable was international experience, also reflected by whether expansion occurred after Poland joined the European Union (EU).

A subsequent variable was firm industry, as the literature argues that industry implies external conditions that significantly moderates the MP relationship, including minimal revenue threshold for scale economies (Hennart, 2007), initial costs incurred at the inception phase of internationalisation, changes required to adapt to local demands, and types of resources required to expand successfully, e.g. R\&D for technology firms and advertising for firms delivering services (Kirca et al., 2012). Our categorisation of industry features construction, heavy, light, IT and advanced technologies, trade, and services industries, for which we also controlled with dummy variables.

The final control variable related to the overall economic condition which was reflect-ed by real GDP change in EU-15 countries (the number of member countries in the EU prior to the accession of ten candidate countries on 1 May 2004).

\section{Analytical procedures}

In order to verify our research hypotheses, multiple regression analysis was employed. Although we expected a U-curve relationship, we also tested linear and cubic shapes of the MP linkage to gain deeper insight into the empirical findings. Prior to the analysis, we verified whether our assumptions required for this statistical method were met. The variables were normally distributed, which we examined with the Kolmogorov-Smirnov test. There was no presence of heteroskedasticity issue, which we checked with the analysis of scattergrams of standardized residuals. There was no multicollinearity issue between independent variables, which we checked with the Pearson's $r$ correlation coefficient (coefficient value exceeding 0.7 would imply problems with multicollinearity). No autocorrelation was present, which we checked with the Durbin-Watson test. 
Table 1. Sample characteristics

\begin{tabular}{|c|c|c|c|c|c|c|c|}
\hline \multirow{2}{*}{ Sector } & \multirow{2}{*}{ Specific activities } & \multicolumn{2}{|c|}{ Large firms, $N=58$} & \multicolumn{2}{|c|}{ Medium firms, $N=39$} & \multicolumn{2}{|c|}{ Total, $\mathbf{N}=97$} \\
\hline & & $\#$ & $\%$ & $\#$ & $\%$ & $\#$ & $\%$ \\
\hline \multirow{4}{*}{$\begin{array}{l}\text { Construction } \\
\text { sector }\end{array}$} & construction firms & 9 & $9.2 \%$ & 2 & $2.1 \%$ & 11 & $11.3 \%$ \\
\hline & developers & - & - & 1 & $1.0 \%$ & 1 & $1.0 \%$ \\
\hline & construction materials & 5 & $5.2 \%$ & 2 & $2.1 \%$ & 7 & $7.3 \%$ \\
\hline & Total & 14 & $14.4 \%$ & 5 & $5.2 \%$ & 19 & $19.6 \%$ \\
\hline \multirow{5}{*}{$\begin{array}{c}\text { Trade } \\
\text { and } \\
\text { services }\end{array}$} & retail trade & 3 & $3.2 \%$ & 1 & $1.0 \%$ & 4 & $4.2 \%$ \\
\hline & wholesale trade & 4 & $4.1 \%$ & 4 & $4.1 \%$ & 8 & $8.2 \%$ \\
\hline & hotels and restaurants & 1 & $1.0 \%$ & - & - & 1 & $1.0 \%$ \\
\hline & other services & 1 & $1.0 \%$ & 3 & $3.1 \%$ & 4 & $4.1 \%$ \\
\hline & Total & 9 & $9.3 \%$ & 8 & $8.2 \%$ & 17 & $17.5 \%$ \\
\hline \multirow{6}{*}{$\begin{array}{l}\text { Heavy } \\
\text { industry }\end{array}$} & chemical & 1 & $1.0 \%$ & - & $0.0 \%$ & 1 & $1.0 \%$ \\
\hline & electromachinery & 8 & $8.3 \%$ & 4 & $4.1 \%$ & 12 & $12.4 \%$ \\
\hline & energy & - & - & 1 & $1.0 \%$ & 1 & $1.0 \%$ \\
\hline & metal & 9 & $9.3 \%$ & 3 & $3.1 \%$ & 12 & $12.4 \%$ \\
\hline & automotive & 3 & $3.1 \%$ & - & - & 3 & $3.1 \%$ \\
\hline & Total & 21 & $21.7 \%$ & 8 & $8.2 \%$ & 29 & $29.9 \%$ \\
\hline \multirow{5}{*}{$\begin{array}{c}\text { Light } \\
\text { industry and } \\
\text { consumer } \\
\text { goods }\end{array}$} & wood & 2 & $2.1 \%$ & - & - & 2 & $2.1 \%$ \\
\hline & light industry & 1 & $1.0 \%$ & 4 & $4.1 \%$ & 5 & $5.1 \%$ \\
\hline & food & 6 & $6.2 \%$ & 3 & $3.1 \%$ & 9 & $9.3 \%$ \\
\hline & artificial materials & 1 & $1.0 \%$ & 3 & $3.1 \%$ & 4 & $4.1 \%$ \\
\hline & Total & 10 & $10.3 \%$ & 10 & $10.3 \%$ & 20 & $20.6 \%$ \\
\hline \multirow{4}{*}{$\begin{array}{l}\text { High-tech } \\
\text { sector }\end{array}$} & pharmaceuticals & 1 & $1.0 \%$ & 1 & $1.0 \%$ & 2 & $2.0 \%$ \\
\hline & IT & 3 & $3.1 \%$ & 6 & $6.3 \%$ & 9 & $9.4 \%$ \\
\hline & telecommunications & - & - & 1 & $1.0 \%$ & 1 & $1.0 \%$ \\
\hline & Total & 4 & $4.1 \%$ & 8 & $8.3 \%$ & 12 & $12.4 \%$ \\
\hline \multicolumn{2}{|r|}{ TOTAL } & 58 & $59.8 \%$ & 39 & $40.2 \%$ & 97 & $100.0 \%$ \\
\hline
\end{tabular}

Source: own study.

Moreover, we used the Cook's distance measure to identify influencing outliers, which indicated values greater than 1.0 as influential. As the data on internationalisation degree measured by FSTS were significantly skewed (high value of skewness), we transformed it using the natural logarithm function to ensure normal distribution of that variable. The characteristics of our sample are reported in Table 1.

As we employed a panel data set in our study, we considered whether to estimate either fixed effects or random effects models as they may generate different results. One of the major preconditions to use random effects models was that observations should be selected randomly from a given population (Dougherty, 2011). In our study, this assumption was not met as our initial sample consisted of all firms listed on the Warsaw Stock Exchange, and they cannot be considered a random sample. Thus, we decided to employ the fixed-effects model.

\section{RESULTS AND DISCUSSION}

The results of the moderated panel regression are reported in Table 2. We found that the M-P relationship fits an inverted U-shape curve for all dependent variables except from ROE, thus providing partial support for our baseline Hypothesis 1 . The reasons that ROE did not exhibit a significant M-P linkage could be found in the observed high fluctuations in firms' equity over the eight-year period covered. In turn, this could have been not only the result of achieved financial performance but also of the firm's dividend policy, merger and acquisition transactions, and other reasons. Consequently, they could have a strong impact on return on equity precluding from identifying a significant MP relationship for this dependent variable. The inverted U-shape of the MP linkage allowed for making inferences about the 
optimal degree of internationalisation to maximize performance in terms of profitability and firm growth. Depending on the variable, the maximum point was achieved at FSTS between $12 \%$ and $13 \%$.

Our findings from the context of newly internationalised firms from a post-transition economy help to understand the apparent inconsistencies in extant findings on the MP relationship (Barłożewski \& Trąpczyński, 2021). Scholars argue that the said relationship may be only a loose association, as there is no specific reason for it to exist (Hennart, 2011; Berry \& Kaul, 2016). However, the question arises whether firms would internationalise if they did not anticipate superior results related to the new activities (Contractor, 2012). We argue that for firms entering the international business environment with limited experience and managerial capabilities, internationalisation generally does bring benefits - up to a certain point, from which these apparent limitations become more impactful. This perspective resonates with the arguments of Powell (2014) in that both insufficient and excessive levels of multinationality can be negatively related to performance. We should also note that newly internationalised firms do not expand out of necessity but rather managerial choice, as in the case of the studied empirical context the home market is large enough to offer early development opportunities, at least in some industries (Sekliuckiene, Jarosiński, \& Kozma, 2019).

Furthermore, with regard to the hypothesised effects of internationalisation motives, the findings for the moderation of market-seeking motives turned out to be significant for sales growth and ROE (Table 2), yet the moderating term coefficient had a negative sign, thus indicating an opposite moderation to the expected relationship. Due to the complexity of interpreting moderating effects, we prepared a graphical representation of the moderating effect of market-seeking motives in two subgroups (where the group corresponding to a low relevance of a given motive embraces survey evaluations below the value of 3.5, while the group corresponding to a high relevance includes values above that threshold). As Figure 2 revealed, the curve for stronger market-seeking motives did become flatter for lower FSTS levels, but the curve declined more steeply for higher FSTS levels. Paradoxically, a sharper focus on market-seeking motivations in foreign expansion based on the experience of "new" multinationals could not turn out to be sustainable in the end. Therefore, on the whole, we found no support for Hypothesis 2 . However, we should note that the size effect measured by the adjusted $\mathrm{R}^{2}$ was between $11.6 \%$ and $15.7 \%$, which can be considered moderate.

Table 2. Findings of moderated panel regression for firm performance

\begin{tabular}{|c|c|c|c|c|}
\hline Explanatory variables & Model 1 & Model 2 & Model 3 & Model 4 \\
\hline Year & -0.004 & $-0.004^{*}$ & $-0.004^{* *}$ & $-0.008^{* * *}$ \\
\hline Intercept & $-3.037^{* * *}$ & $-0.799^{* * *}$ & $-0.808^{* * *}$ & $-1.107^{* * *}$ \\
\hline Main effects & & & \\
\hline FSTS & $-0.047+$ & $-0.016^{\dagger}$ & $-0.023^{* *}$ & -0.007 \\
\hline H1: (FSTS)^2 & -0.006 & $-0.004^{*}$ & $-0.006^{* * *}$ & 0.000 \\
\hline Market-seeking motives & -0.008 & 0.004 & -0.009 & 0.014 \\
\hline Home and host country institutional motives & -0.008 & $-0.017^{*}$ & $-0.016^{*}$ & $-0.026^{*}$ \\
\hline Efficiency-seeking motives & -0.002 & -0.009 & $-0.020^{*}$ & $-0.023^{\dagger}$ \\
\hline Motives relating to competitive pressures & -0.017 & 0.004 & $0.016^{*}$ & 0.003 \\
\hline \multicolumn{2}{|c|}{ Moderating effects } & & $-0.013^{*}$ \\
\hline H2: FSTS x market-seeking motives & $-0.016 \dagger$ & -0.002 & -0.005 & -0.001 \\
\hline H3: FSTS x home and host country institutional \\
motives
\end{tabular}




\begin{tabular}{|c|c|c|c|c|}
\hline Explanatory variables & Model 1 & Model 2 & Model 3 & Model 4 \\
\hline \multicolumn{2}{|c|}{ Control variables } \\
\hline Firm size & $0.067^{* * *}$ & $0.018^{*}$ & $0.013^{* *}$ & $0.039^{* *}$ \\
\hline Firm age & 0.018 & 0.001 & $0.017 \dagger$ & 0.023 \\
\hline Geographic diversification & 0.002 & $0.007^{* * *}$ & $0.006^{* * *}$ & $0.006^{* *}$ \\
\hline Internationalisation since 2004 (1) & -0.006 & $-0.016 \dagger$ & $-0.027^{* *}$ & $-0.043^{* * *}$ \\
\hline Building and heavy construction (2) & -0.028 & -0.002 & -0.001 & 0.002 \\
\hline Light manufacturing industry (2) & 0.015 & 0.011 & 0.015 & 0.012 \\
\hline Wholesale and retail trade, services (2) & $0.047 \dagger$ & -0.005 & 0.003 & 0.017 \\
\hline IT and new technologies industry (2) & 0.002 & 0.017 & 0.000 & -0.003 \\
\hline GDP change (UE-15) in real terms & $0.030^{* * *}$ & $0.008^{* * *}$ & $0.008^{* * *}$ & $0.012^{* * *}$ \\
\hline $\mathrm{R}^{2}$ adj. & 0.157 & 0.116 & 0.154 & 0.129 \\
\hline $\mathrm{F}$ & $6.860^{* * *}$ & $5.702^{* * *}$ & $7.712^{* * *}$ & $6.235^{* * *}$ \\
\hline $\mathrm{N}$ & 630 & 716 & 729 & 708 \\
\hline
\end{tabular}

Significance levels: ${ }^{*} \mathrm{p}<0.01 ;{ }^{*} \mathrm{p}<0.05 ; \mathrm{\dagger}<<0.1$ Dependent variables: Model 1 - Sales growth, Model 2 - ROS, Model 3 ROA, Model $4-$ ROE. (1) Benchmark values relate to "Expansion before 2004" (entry of Poland into the EU). (2) Benchmark values relate to "Heavy manufacturing industry".

Source: own study.

On the contrary, in the inverted U-shape for sales growth (Model 1 in Table 2), the effect of the degree of internationalisation was positively moderated by institutional motives. In other words, the inverted U-shape was flatter for firms driven more strongly by institutional factors. In order to facilitate the interpretation of this effect, we provided a visual interpretation of the moderation in Figure 3. Accordingly, we found support for Hypothesis 3.

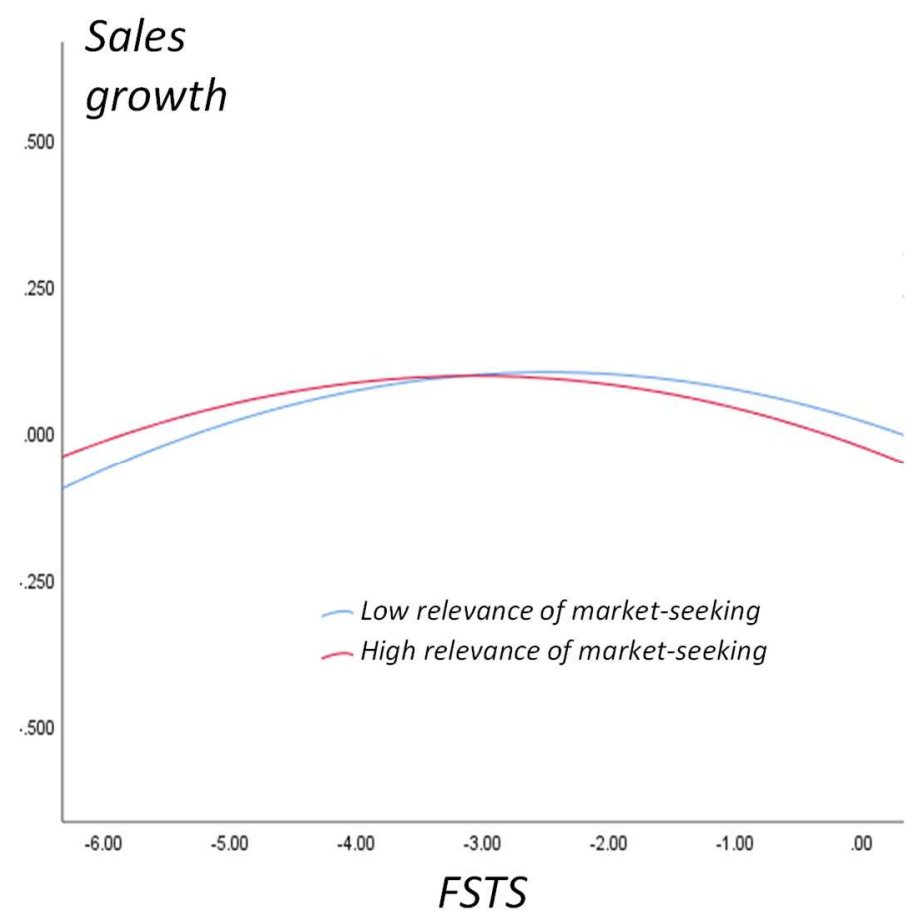

Figure 2. Moderating effect of market-seeking motives Source: own elaboration. 


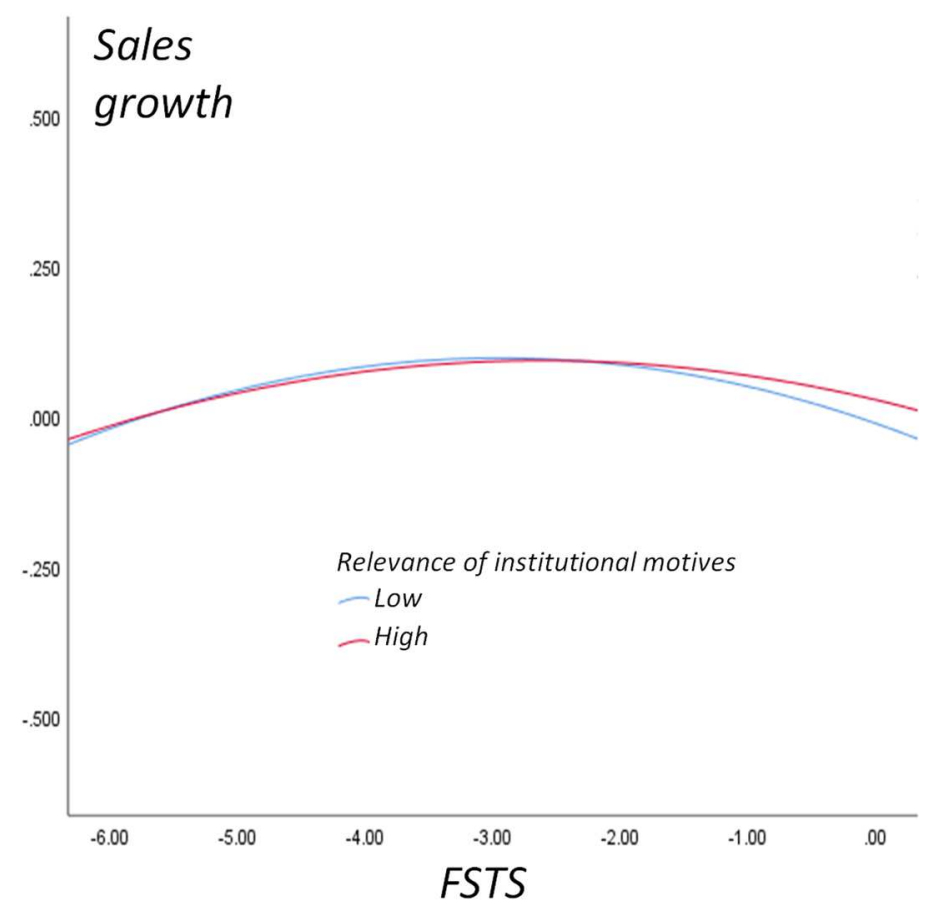

Figure 3. Moderating effect of institutional motives Source: own elaboration.

Furthermore, we found that efficiency-seeking motives positively moderate the inverted Ushape for both ROA and ROS, based on the regression results. The findings for efficiency-seeking motives may be explained by higher costs arising from liability of newness and foreignness compared to potential savings achieved through deployment of operations across borders. The regression results suggested that going abroad with efficiency-seeking motive in mind could be beneficial in terms of profitability measured by ROA and ROS in the long-term, after a higher degree of internationalisation is achieved. However, our complementary analysis of the moderated curves demonstrated some ambiguous findings (Figure 4). In fact, for both ROS and ROA, the moderating effect seemed to be negative, with the performance declining for higher levels of multinationality if the focus on cost efficiency was predominant. This would suggest that in the case of early-stage multinationals, the ability of managing cross-border efficiency-oriented operations may not turn out beneficial from the viewpoint of the entire firm.

Finally, for competitive pressure-related motives, we found support for their positive moderating effect for the effect of internationalisation on ROE (and negative for ROS), thus providing partial evidence in support of Hypothesis 5 . In fact, internationalisation driven by competitive pressure is not oriented towards short-term profitability or cost-efficiency, as it is guided by more long-term, strategic premises. The graphical interpretation of moderations shown in Figure 5 corroborates this assertion.

To summarise the findings on the moderating role of internationalisation motives, we answer extant calls to decompose the contextual complexity behind the MP relationship (Griffith, Cavusgil, \& Xu, 2008; Contractor, 2012; Kirca et al., 2012; Tallman \& Pedersen, 2012; Yildiz, 2013; Berry \& Kaul, 2016; Dittfeld, 2017). By decomposing performance into distinct dimensions, we show that internationalisation undertaken with different underlying logics has distinct implications from the parent firm's viewpoint (Trąpczyński, 2016). While scholars acknowledge that effects of the internationalisation degree must be considered from the perspective of motives (e.g. Jain \& Prakash, 2016), they did not analyse the specific performance implications of various motives in a multidimensional manner. 


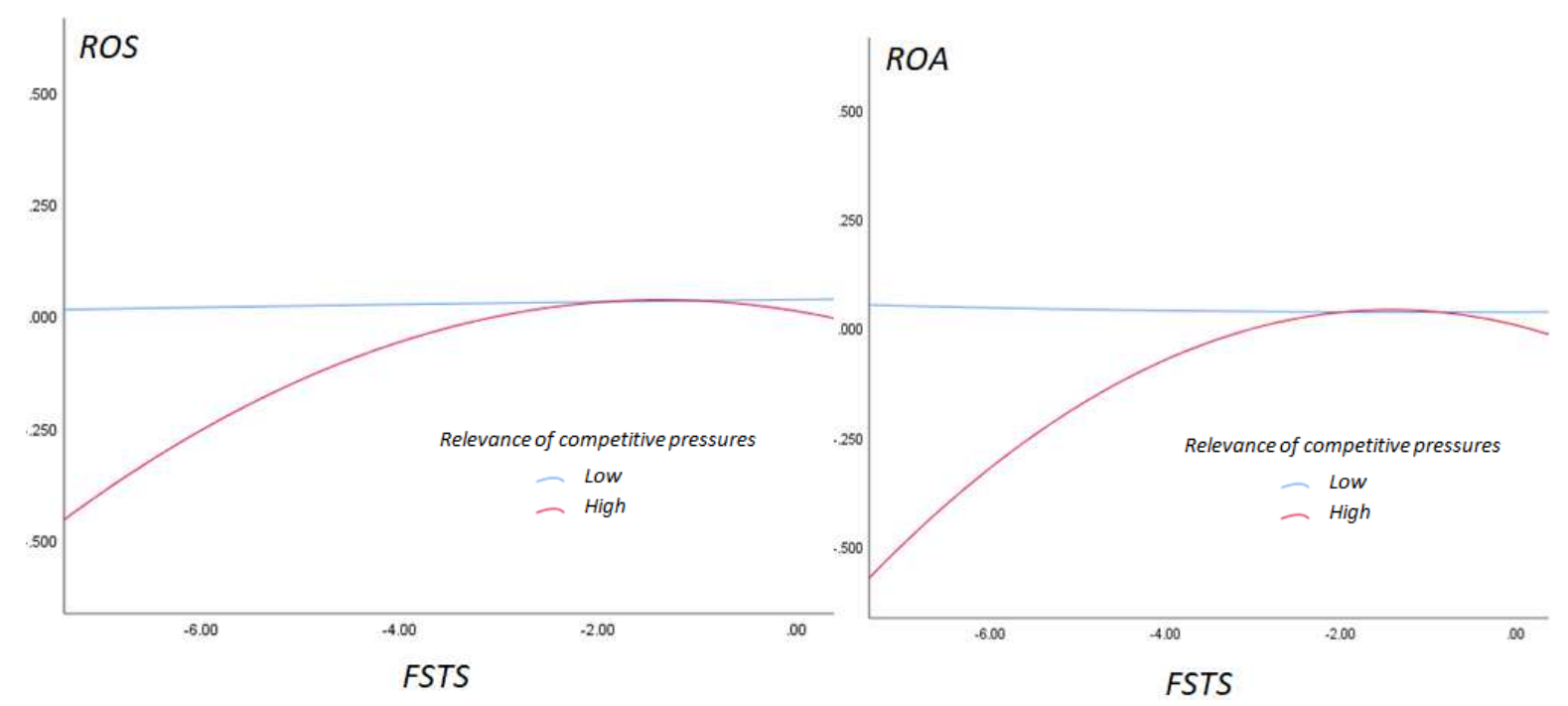

Figure 4. Moderating effect of efficiency seeking motives Source: own elaboration.
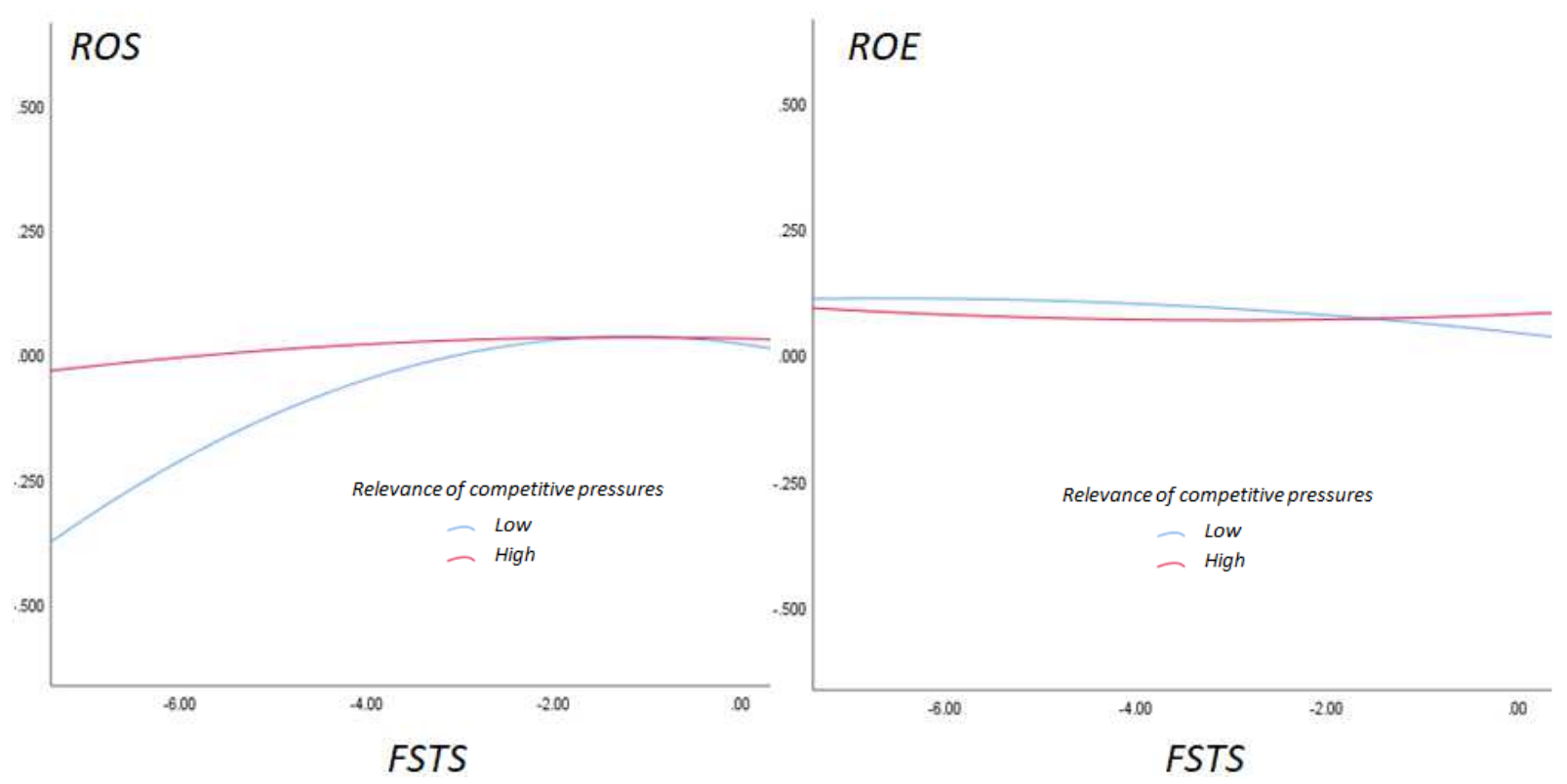

Figure 5. Moderating effect of competitive pressure-related motives Source: own elaboration.

Among the control variables, only a few provided evidence of a significant effect, including firm size, geographical diversification, starting expansion after Poland accession to the EU and real GDP change in EU-15 countries. With regard to firm size, the findings suggest that larger companies achieved better financial performance than smaller firms, which confirms the analysis in the previous sections. In the case of Polish companies, this finding should be explained by access to larger resources and years of experience accumulated in the international arena.

The results for geographical diversification suggest that firms operating in a larger number of markets achieve higher profitability of assets and sales. This may lead to the conclusion that geographical diversification may reduce total risk. As far as firm experience goes, firms with the lowest experience - i.e. those which started foreign expansion after Poland accessed the EU - exhibited significantly lower results than other companies. Finally, a very significant control variable was real change in GDP 
of EU-15 countries, which are the main exporting partners of Polish firms. All this leads us to the conclusion that the GDP variable should be mandatory present in the future longitudinal research.

\section{CONCLUSIONS}

The relationship of the degree of internationalisation with firm performance is a continuously growing area of research, and studies devoted to newly internationalised firms from post-transition economies can pose a fertile ground for refining current knowledge in the field. In conjunction with continuously evolving views on the nature of the MP linkage, this warrants further discussion on that subject, especially when longer periods of analysis and - so far largely neglected - contextual variables are considered. This article contributes to the advancement of the MP relationship analysis in two ways. Firstly, we conducted a longitudinal analysis, which is arguably one of the very few such attempts in the CEE region. This analysis offers a strong support for an inverted U-shape MP relationship, which in turn proves to be contrary to theoretical predictions based upon commonly adopted S-curve in advanced economies.

The empirical findings seem to be more in line with the first two stages of the recently proposed M-curve, i.e. the "global illusion" and subsequent fall in performance. we may expect that the inverted observed U-relation would change with the increasing multinationality level of Polish firms. Then, new stages in the MP relationship could emerge giving empirical evidence for the inverted S-curve and, eventually, for the M-curve.

The unique contribution of our study pertains to the differentiated role of internationalisation motives on the relationship between multinationality and performance. At the same time, the study shows that performance is not a monolithic construct, and therefore different types of international operations have distinct effects on performance. We incorporated a large set of contextual variables, providing more texture to the frequently superficial treatment of internationalisation.

Among the tested control variables, a significant effect was observed for firm size, international experience, geographical diversification into dissimilar markets, and general economic conditions measured by percentage change of real GDP. Control variables not significant in the analysis comprised firm industry and firm age. This may lead to the conclusion that the contextual nature of the MP relationship can be related only to a limited set of variables, whose nature still must be identified and influence explained. We based our study on a limited empirical sample due to the constraints of data access. Future studies should use larger firm samples in a broader variety of industry settings in order to better control for sectoral effects, but also to capture more contextual effects. Moreover, studies recurring to more recent data could be used in order to compare the findings of the present study with the development of firms that were exposed to challenges of changing global environment and adjusted their business models accordingly. Still, the predominance of SMEs among the new multinationals under study here makes the findings relatively stable over time, since most fundamentals of the internationalisation process of these firms have not changed over the last couple of years, with hightech and services constituting the minority of the sample.

However, let us note that the growing internationalisation degree of Polish firms may reveal other shapes of the MP linkage in the future. Based upon the findings from this study, we should first expect to see an inverted S-curve and eventually also an M-curve. The latter should be observed when Polish companies close the gap in terms of advancement in international activities between them and firms from developed countries. In turn, this will require not only the active exploitation of foreign markets but also the introduction of adequate internal changes to drive performance.

\section{REFERENCES}

Almodovar, P. (2012). The international performance of standardising and customising Spanish firms. The M curve relationships. Multinational Business Review, 20(4), 306-330. https://doi.org/10.1108/15253831211286246

Androniceanu, A.- M., Kinnunen, J., Georgescu, I., \& Androniceanu, A. (2020). A multidimensional approach to competitiveness, innovation and well-being in the EU using canonical correlation analysis. Journal of Competitiveness, 12(4), 5-21. https://doi.org/10.7441/joc.2020.04.01 
Annavarluja, M., \& Beldona, S. (2000). Multinationality - performance: a review and reconceptualisation. International Journal of Organisational Analysis, 8(1), 48-67. https://doi.org/10.1108/eb028910

Barłożewski, K. (2018). Is Foreign Expansion an Effective Way to Boost Sales and Profits?. Journal of Management and Financial Sciences, 32, 71-82.

Barłożewski, K., \& Trąpczyński, P. (2021). Is internationalisation beneficial for novice internationalisers? The performance effects of firm-specific advantages, internationalisation degree and firm size revisited. Oeconomia Copernicana, 12(1), 53-75. https://doi.org/10.24136/oc.2021.003.

Bausch, A., \& Krist, M. (2007). The effect of context-related moderators on the internationalization-performance relationship: Evidence from meta-analysis. Management International Review, 47(3), 319-347. https://doi.org/10.1007/s11575-007-0019-z

Benito, G.R.G. (2015). Why and how motives (still) matter. The Multinational Business Review, 23(1), 15-24. https://doi.org/10.1108/MBR-02-2015-0005

Benito, G.R.G., \& Welch, L.S. (1997). De-internationalisation. Management International Review, 37(2), 7-25.

Berry, H., \& Kaul, A. (2016). Replicating the multinationality-performance relationship: Is there an S-curve?. Strategic Management Journal, 37(11), 2275-2290. https://doi.org/10.1002/smj.2567

Bilan Y., Mishchuk, H., Roshchyk, I. \& Joshi, O. (2020). Hiring and retaining skilled employees in SMEs: problems in human resource practices and links with organizational success. Business: Theory and Practice, 21(2), 780791. DOI: https://doi.org/10.3846/btp.2020.12750

Brouthers, K.D., Brouthers, L.E., \& Werner, S. (2008). Resource-based advantages in an international context. Journal of Management, 34(2), 189-217. https://doi.org/10.1177/0149206307312508

Bučiūnienè, I. (2018). The transformation of economies and societies in Central and Eastern Europe-how has it contributed to management and organisation science?. Journal of East European Management Studies, 23(4), 693-701. https://doi.org/10.5771/0949-6181-2018-4-694

Capar, N., \& Kotabe, M. (2003). The relationship between international diversification and performance in service firms. Journal of International Business Studies, 34(4), 345-355. https://doi.org/10.1057/palgrave.jibs.8400036

Caputo, A., Pellegrini, M.M., Dabic, M., \& Dana, L.P. (2016). Internationalisation of firms from Central and Eastern Europe. European Business Review, 28(6), 630-651. https://doi.org/10.1108/EBR-01-2016-0004

Chan, C.M., Isobe, T., \& Makino, S. (2008). Which country matters? Institutional development and foreign affiliate performance. Strategic Management Journal, 29(11), 1179-1205. https://doi.org/ 10.1002/smj.705

Chen, Y., Jiang, Y., Wang, C., \& Hsu, W.C. (2014). How do resources and diversification strategy explain the performance consequences of internationalization?. Management Decision, 52(5), 897-915. https://doi.org/10.1108/MD-10-2013-0527

Cieślik, A., Michałek, J. J., \& Szczygielski, K. (2019). What matters for firms' participation in Global Value Chains in Central and East European countries?. Equilibrium. Quarterly Journal of Economics and Economic Policy, 14(3), 481-502. https://doi.org/10.24136/eq.2019.023.

Cieślik, A., \& Michałek, J. J. (2018). Process and product innovations, multi-product status and export performance: firm-level evidence from V? 4 countries. Equilibrium. Quarterly Journal of Economics and Economic Policy, 13(2), 233-250. https://doi.org/10.24136/eq.2018.012.

Contractor, F.J. (2012). Why do multinational firms exist? A theory note about the effect of multinational expansion on performance and recent methodological critiques. Global Strategy Journal, 2(4), 318-331. https://doi.org/10.1111/j.2042-5805.2012.01045.x

Contractor, F.J. (2007). Is international business good for companies? The evolutionary or multi-stage theory of internationalization vs. the transaction cost perspective. Management International Review, 47(3), 453-475. https://doi.org/10.1007/s11575-007-0024-2

Contractor, F.J., Kundu, S.K., \& Hsu, C.C. (2003). A three-stage theory of international expansion: The link between multinationality and performance in the service sector. Journal of International Business Studies, 34(1), 5-18. https://doi.org/10.1057/palgrave.jibs.8400003

Demirbag, M., Tatoglu, E., \& Glaister, K.W. (2007). Factors influencing perceptions of performance: The case of western FDI in an emerging market. International Business Review, 16(3), 310-336. https://doi.org/10.1016/j.ibusrev.2007.02.002

Dittfeld, M. (2017). Multinationality and performance: A context-specific analysis for German firms. Management International Review, 57(1), 1-35. https://doi.org/10.1007/s11575-016-0286-7 
Dörrenbächer, C. (2000). Measuring corporate internationalisation: A review of measurement concepts and their use. Intereconomics, 35(3), 119-126. https://doi.org/10.1007/BF02927197

Doryń, W., \& Stachera, D. (2008). Wpływ internacjonalizacji na wyniki ekonomiczne największych polskich przedsiębiorstw przemysłowych. Gospodarka Narodowa, 11-12.

Dougherty, C. (2011). Introduction to econometrics. New York: Oxford University Press.

Dunning, J.H. (1988a). The Eclectic Paradigm of International Production: A Restatement and Some Possible Extensions. Journal of International Business Studies, 19(1), 1-31. Retrieved from https://www.jstor.org/stable/154984 on September 20, 2020.

Dunning, J.H. (1988b). The theory of international production. The International Trade Journal, 3(1), 21-66. https://doi.org/10.1080/08853908808523656

Dunning, J.H. (1993). Multinational Enterprises and the Global Economy. Harlow: Addison-Wesley Publication Company.

Dunning, J.H., \& Lundan, S.M. (2008). Multinational Enterprises and the Global Economy. Cheltenham: Edward Elgar.

Elango, B. (2012). How industry dynamics influence the internationalization-performance relationship: Evidence from technology-intensive firms. Thunderbird. International Business Review, 54(5), 653-665. https://doi.org/10.1002/tie.21491

Estrin, S., Baghdasaryan, D., \& Meyer, K.E. (2009). The impact of institutional and human resource distance on international entry strategies. Journal of Management Studies, 46(7), 1171-1196. https://doi.org/10.1002/tie.21491. https://doi.org/10.1111/j.1467-6486.2009.00838.x

Fang, Y., Wade, M., Delios, A., \& Beamish, P.W. (2013). An exploration of multinational enterprise knowledge resources and foreign subsidiary performance. Journal of World Business, 48(1), 30-38. https://doi.org/10.1016/j.jwb.2012.06.004

Geleilate, J.M.G., Magnusson, P., Parente, R.C., \& Alvarado-Vargas, M.J. (2016). Home country institutional effects on the multinationality-performance relationship: a comparison between emerging and developed market multinationals. Journal of International Management, 22(4), 380-402. https://doi.org/10.1016/j.intman.2016.06.001

Geringer, J.M., Tallman, S., \& Olsen, D.M. (2000). Product and international diversification among Japanese multinational firms. Strategic Management Journal, 21(1), 51-80. https://doi.org/10.1002/(SICI)1097-0266(200001)

Glaum, M., \& Oesterle, M.J. (2007). 40 years of research on internationalization and firm performance: more questions than answers?. Management International Review, 47(3), 307-317. https://doi.org/10.1007/s11575-007-0018-0

Globerman, S., \& Shapiro, D.M. (1999). The impact of government policies on foreign direct investment: The Canadian experience. Journal of International Business Studies, 30(3), 513-532.

Głodowska, A., Pera, B., \& Wach, K. (2019). International strategy as the facilitator of the speed, scope, and scale of firms' internationalization. Central European Management Journal, 27(3), 55-84. http://dx.doi.org/10.7206/cemj.2658-0845.3

Gołaś, Z., Bieniasz, A., \& Czerwińska-Kayzer, D. (2009). Rentowność kapitału własnego przedsiębiorstwa. Ekonomika i Organizacja Przedsiębiorstwa, (8), 43-51.

Gorynia, M., Nowak, J., Trąpczyński, P., \& Wolniak, R. (2015). Does outward FDI by Polish multinationals support existing theory? Findings from a quantitative study. Economics and Business Review, 1(4), 84. https://doi.org/10.18559/ebr.2015.4.6

Gorynia, M., Trąpczyński, P., \& Bytniewski, S. (2019). The concepts of strategy and business models in firm internationalization research: Towards a research agenda. International Entrepreneurship Re-view, 5(2), 7-21. https://doi.org/10.15678/IER.2019.0502.01

Griffith, D.A., Cavusgil, S.T., \& Xu, S. (2008). Emerging themes in international business research. Journal of International Business Studies, 39(7), 1220-1235. https://doi.org/10.1057/palgrave.jibs.8400412

Gu, J., Yang, Y., \& Strange, R. (2018). Location choice, ownership structure and multinational performance. Multinational Business Review, 26(3), 250-276. https://doi.org/10.1108/MBR-12-2017-0105

Gugler, P. (2019). Assessing the competitiveness of locations: A journey through the major theoretical insights. Economics and Business Review, 19(3), 16-34. https://doi.org/10.18559/ebr.2019.3.2

Habib, M., \& Zurawicki, L. (2002). Corruption and foreign direct investment. Journal of International Business Studies, 33(2), 291-307. https://doi.org/10.1057/palgrave.jibs.8491017 
Haller, A. (2020). From classical and neoclassical economic growth to degrowth in Europe. Challenges for public administration. Administratie si Management Public, 34, 150-170. DOI: 10.24818/amp/2020.34-9

Hennart, J.F. (2007). The theoretical rationale for a multinationality-performance relationship. Management International Review, 47(3), 423-452. https://doi.org/10.1007/s11575-007-0023-3

Hoskisson, R.E., Wright, M., Filatotchev, I., \& Peng, M.W. (2013). Emerging multinationals from mid-range economies: The influence of institutions and factor markets. Journal of Management Studies, 50(7), 1295-1321. https://doi.org/10.1111/j.1467-6486.2012.01085.x

Jain, N.K., \& Prakash, P. (2016). Multinationality and performance: The moderating influence of internationalization motives and resources. International Studies of Management \& Organization, 46(1), 35-49. https://doi.org/10.1080/00208825.2015.1007010

Janšto, E., Polakovič, P., Hennyeyová, K., \& Slováková, I. (2019). Analysis of the current support of E-marketing activities in selected enterprises of the wine sector in slovakia. Agris on-Line Papers in Economics and Informatics, 11(4), 31-34. https://doi.org/10.7160/aol.2019.110403

Jaworek, M. (2013). Ocena ekonomicznej efektywności bezpośrednich inwestycji zagranicznych w praktyce polskich przedsiębiorstw. Toruń: Wydawnictwo Naukowe Uniwersytetu Mikołaja Kopernika.

Karasiewicz, G. (2013). Marketingowe strategie internacjonalizacji polskich przedsiębiorstw. Podejście holistyczne. Warszawa: Oficyna Wolters Kluwer Business.

Kindleberger, C. (1969). American Business Abroad. Six Lectures of Direct Investment. Yale University Press, New Haven, London.

Kirca, A.H., Roth, K., Hult, G.T.M., \& Cavusgil, S.T. (2012). The role of context in the multinationality-performance relationship: A meta-analytic review. Global Strategy Journal, 2(2), 108-121. https://doi.org/ 10.1002/gsj.1032

Kirca, A.H., Fernandez, W.D., \& Kundu, S.K. (2016). An empirical analysis and extension of internalization theory in emerging markets: The role of firm-specific assets and asset dispersion in the multinationality-performance relationship. Journal of World Business, 51(4), 628-640. https://doi.org/10.1016/j.jwb.2016.03.003

Kosach, I., Duka, A., Starchenko, G., Myhaylovska, O., Zhavoronok, A. (2020). Socioeconomic viability of public management in the context of European integration processes. Administratie si Management Public, 35, 139-152. https://doi.org/10.24818/amp/2020.35-09

Krajčírová, R., Vaňová, A. F., \& Munk, M. (2019). What is relationship between profits and dividends in agricultural legal entities? Agris on-Line Papers in Economics and Informatics, 11(1), 55-64. https://doi.org/10.7160/aol.2019.110106

Lee, C.W., \& Fernando, A. (2020). Can internally generated FDI impact export performance? The study on Indonesia in the years 1980-2018. International Entrepreneurship Review, 6(1), 29-45. https://doi.org/10.15678/IER.2020.0601.02

Lee, I.H. (2010). The M curve: the performance of born-regional firms from Korea. Multinational Business Review, 18(4), 1-22. https://doi.org/10.1108/1525383X201000017

Li, C.S.J., Henley, J., Ansell, J., \& Dong, T.P. (2011). Location-specific factors, localisation strategy, and firm performance: A case study of Taiwanese manufacturing MNE subsidiaries investing in China. Tijdschrift Voor Economische en Sociale Geografie, 102(4), 426-440. https://doi.org/10.1111/j.1467-9663.2010.00646.x

Li, L. (2005). Is regional strategy more effective than global strategy in the US service industries?. Management International Review, 37-57.

Li, L. (2007). Multinationality and performance: A synthetic review and research agenda. International Journal of Management Reviews, 9(2), 117-139. https://doi.org/10.1111/j.1468-2370.2007.00205.x

López-Morales, J.S., \& Gómez-Casas, M.M. (2014). Degree of internationalization (DOI) and performance relationship: an empirical and conceptual approach. International Journal of Academic Research in Business and Social Sciences, 4(9), 39. https://doi.org/10.6007/IJARBSS/v4-i9/1128

Maciejewski, M., \& Wach, K. (2019). International Startups from Poland: Born Global or Born Regional?. Journal of Management and Business Administration Central Europe, 27(1), 60-83. https://doi.org/10.7206/jmba.ce.2450-7814.247

Matysiak, L., \& Bausch, A. (2012). Antecedents of MNE performance: blinded by the obvious in 35 years of literature. Multinational Business Review, 20(2), 178-211. https://doi.org/10.1108/15253831211238230 
Miller, S.R., Lavie, D., \& Delios, A. (2016). International intensity, diversity, and distance: Unpacking the internationalization-performance relationship. International Business Review, 25(4), 907-920. https://doi.org/10.1016/j.ibusrev.2015.12.003

Mullen, C., \& O'Hagan Luff, M. (2018). Alphabet soup: the relationship between multinationality and firm performance. Transnational Corporations Review, 10(4), 409-423. https://doi.org/10.1080/19186444.2018.1556519

Nguyen, Q.T. (2011). The empirical literature on multinational enterprises, subsidiaries and performance. Multinational Business Review, 19(1), 47-64. https://doi.org/10.1108/15253831111126749

Nguyen, Q.T. (2017). Multinationality and performance literature: A critical review and future research agenda. Management International Review, 57(3), 311-347. https://doi.org/10.1007/s11575-016-0290-y

Nguyen, Q.T., \& Kim, S. (2020). The multinationality and performance relationship: Revisiting the literature and exploring the implications. International Business Review, 29(2), 101670.

Nwabueze, U., \& Mileski, J. (2018). Achieving competitive advantage through effective communication in a global environment. Journal of International Studies, 11(1), 50-66. doi:10.14254/2071-8330.2018/11-1/4

Obloj, K. (2019). Footnotes to organizational competitiveness. Economics and Business Review, 19(3), 35-49. https:/doi.org/10.18559/ebr.2019.3.3

Pokorná, P., Šebestová, J., \& Čemerková, Š. (2019). Dilemma of Directions for Reinvestment. Forum Scientiae Oeconomia, 7(4), 83-99. https://doi.org/10.23762/FSO_VOL7_NO4_6

Powell, K.S. (2014). From M-P to MA-P: Multinationality alignment and performance. Journal of International Business Studies, 45(2), 211-226. https://doi.org/10.1057/jibs.2013.63

Paliokaite, A. (2019). An innovation policy framework for upgrading firm absorptive capacities in the context of catching-up economies. Journal of Entrepreneurship, Management and Innovation, 15(3), 103-130. https://doi.org/10.7341/20191534

Purkayastha, A., Sharma, S., \& Karna, A. (2020). Theoretical foundations of antecedents of internationalization and moderators in multinationality-performance relationship. Cross Cultural \& Strategic Management, 27(2), 213-243. https://doi.org/10.1108/CCSM-03-2019-0055

Qian, G. (2002). Multinationality, product diversification, and profitability of emerging US small-and medium-sized enterprises. Journal of Business Venturing, 17(6), 611-633. https://doi.org/10.1016/S0883-9026(01)00080-5

Ramamurti, R. (2009). Why study emerging-market multinationals? In R. Ramamurti, \& J.V. Singh (Eds.), Emerging Multinationals in Emerging Markets (pp. 3-22). Cambridge: Cambridge University Press.

Riahi-Belkaoui, A. (1998). The effects of the degree of internationalization on firm performance. International Business Review, 7(3), 315-321. https://doi.org/10.1016/S0969-5931(98)00013-4

Richter, N.F., Schmidt, R., Ladwig, T.J., \& Wulhorst, F. (2017). A critical perspective on the measurement of performance in the empirical multinationality and performance literature. Critical Perspectives on International Business, 12(2), 94-118. https://doi.org/10.1108/cpoib-06-2013-0015

Rodriguez, P., Uhlenbruck, K., \& Eden, L. (2005). Government Corruption and the Entry Strategies of Multinationals. Academy of Management Review, 30(2), 383-396. https://doi.org/10.5465/AMR.2005.16387894

Rugman, A.M., \& Oh, C.H. (2011). Methodological issues in the measurement of multinationality of US firms. Multinational Business Review, 19(3), 202-212. https://doi.org/10.1108/15253831111172630

Ruigrok, W., \& Wagner, H. (2004). Internationalisation and firm performance: Meta-analytic review and future research directions. Working Paper, University of St. Gallen.

Sedziniauskiene, R., Sekliuckiene, J., \& Zucchella, A. (2019). Networks' impact on the entrepreneurial internationalization: A literature review and research agenda. Management International Review, 59(5), 779-823. https://doi.org/10.1007/s11575-019-00395-6

Sekliuckiene, J., Jarosiński, M., \& Kozma, M. (2019). Entrepreneurial level factors of early internationalization: A cross country comparison. Engineering Economics, 30(2), 223-235. https://doi.org/10.5755/j01.ee.30.2.21185

Shin, J., Mendoza, X., Hawkins, M.A., \& Choi, C. (2017). The relationship between multinationality and performance: Knowledge-intensive vs. capital-intensive service micro-multinational enterprises. International Business Review, 26(5), 867-880. https://doi.org/10.1016/j.ibusrev.2017.02.005

Sikora, T., \& Baranowska-Prokop, E. (2018). Explaining success perception of Polish international new ventures: Four perspectives. Economics and Sociology, 11(4), 106-127. doi:10.14254/2071-789X.2018/11-4/7 
Singla, C., \& George, R. (2013). Internationalization and performance: A contextual analysis of Indian firms. Journal of Business Research, 66(12), 2500-2506. https://doi.org/10.1016/j.jbusres.2013.05.041

Sullivan, D. (1994). Measuring the degree of internationalization of a firm. Journal of International Business Studies, 25(2), 325-342. https://doi.org/10.1057/palgrave.jibs.8490203

Szałucka, M. (2013). Zagraniczna aktywność inwestycyjna polskich przedsiębiorstw a ich konkurencyjność. In W. Karaszewski (Ed.), Aktywność inwestycyjna polskich przedsiębiorstw za granicq. Czynniki i skutki. Warsaw: PWE.

Tallman, S., \& Pedersen, T. (2012). Editors' Comment on Research Platforms: Point-Counterpoint on Multinationalization and Performance. Global Strategy Journal, 2(4), 313-317. https://doi.org/ 10.1111/j.20425805.2012.01044.x

Tohidi, A., Ghorbani, M., Karbasi, A. -., Asgharpourmasouleh, A., \& Hassani-Mahmooei, B. (2020). Comparison of fuzzy multi-criteria decision-making methods to rank business strategies and marketing resources. Agris onLine Papers in Economics and Informatics, 12(3), 101-114. https://doi.org/10.7160/AOL.2020.120309

Trąpczyński, P. (2016). Foundations of foreign direct investment performance. Poznań: Wydawnictwo Uniwersytetu Ekonomicznego w Poznaniu.

Uhlenbruck, K. (1997). Entry Motives and Firm Capabilities: Performance Implications for Foreign Direct Investment in Central and Eastern Europe. In L.N. Dosier \& J.B. Keys (Eds.), Academy of Management Best Paper Proceedings (pp. 204-208). Boston.

Verbeke, A., \& Brugman, P. (2009). Triple-testing the quality of multinationality-performance research: An internalization theory perspective. International Business Review, 18(3), 265-275. https://doi.org/10.1016/j.ibusrev.2009.01.005

Verbeke, A., \& Forootan, M.Z. (2012). How good are multinationality-performance (M-P) empirical studies?. Global Strategy Journal, 2(4), 332-344. https://doi.org/10.1111/j.2042-5805.2012.01040.x

Verbeke, A., Li, L., \& Goerzen, A. (2009). Toward more effective research on the multinationality-performance relationship. Management International Review, 49(2), 149-161. https://doi.org/ 10.1007/s11575-008-0133-6

Wach, K. (2017). Exploring the Role of Ownership in International Entrepreneurship: How does Ownership Affect Internationalisation of Polish Firms?. Entrepreneurial Business and Economics Review, 5(4), 205-224. https://doi.org/10.15678/EBER.2017.05041043-56. https://doi.org/10.23762/EBER.2017.050410

Xia, Y., Qiu, Y., \& Zafar, A.U. (2007). The impact of firm resources on subsidiary's competitiveness in emerging markets: an empirical study of Singaporean SMEs' performance in China. Multinational Business Review, 15(2), 13-40. https://doi.org/10.1108/1525383X200700006

Yang, Y., \& Driffield, N. (2012). Multinationality-performance relationship. Management International Review, 52(1), 23-47. https://doi.org/10.1007/s11575-011-0095-y

Yang, Y., Martins, P.S., \& Driffield, N. (2013). Multinational performance and the geography of FDI. Management International Review, 53(6), 763-794. https://doi.org/10.1007/s11575-013-0180-5

Yildiz, H.E. (2013). Performance implications of multinationality: moderating role of foreign market entry mode. Multinational Business Review, 21(4), 334-357. https://doi.org/10.1108/MBR-04-2013-0021

Yiu, D., \& Makino, S. (2002). The choice between joint venture and wholly owned subsidiary: An institutional perspective. Organization Science, 13(6), 667-683. https://doi.org/10.1287/orsc.13.6.667.494 


\section{Authors}

The contribution share of authors is equal and amounted to $50 \%$ for each of them.

\section{Krystian Barłożewski}

Assistant Professor at the Warsaw School of Economics, Department of International Management at the Collegium of World Economy. His research interests include internationalization performance and the impact of digital transformation on internationalization models and processes.

Correspondence to: Dr Krystian Barłożewski, Department of International Management, Collegium of World Economy, Warsaw School of Economics, Madalińskiego 6/8, 02-513 Warszawa, Poland; e-mail: kbarlo@sgh.waw.pl

ORCID (1) http://orcid.org/0000-0002-7050-0962

\section{Piotr Trąpczyński}

Associate Professor at the Poznań University of Economics and Business, Department of International Competitiveness at the Institute of International Business and Economics. His research interests include foreign direct investments and divestments, export performance and export exits, along with business models.

Correspondence to: Dr hab. Piotr Trąpczyński, prof. UEP, Department of International Competitiveness, Poznań University of Economics and Business, al. Niepodległości 1, 61-875 Poznań, Poland, e-mail: piotr.trapczynski@ue.poznan.pl ORCID (ib http://orcid.org/0000-0001-8154-9174

\section{Acknowledgements and Financial Disclosure}

This paper was prepared within a research project financed by the research grant of the National Science Centre (Poland) awarded based on the decision no. DEC-2017/27/B/HS4/02344.

\section{Conflict of Interest}

The authors declare that the research was conducted in the absence of any commercial or financial relationships that could be construed as a potential conflict of interest.

\section{Copyright and License}

This article is published under the terms of the Creative Commons

Attribution - NoDerivs (CC BY-ND 4.0) License

http://creativecommons.org/licenses/by-nd/4.0/ 